\title{
JURIDICAL REVIEW OF SHARIA SUPERVISORY BOARD SUPERVISION ON SHARIA BANKING PRODUCTS
}

\author{
Arjan $^{1}$, Hirsanuddin ${ }^{2}$, Muhaimin ${ }^{3}$ \\ 1,2,3 Notary Master Study Program, Faculty of Law, University of Mataram, Indonesia \\ Corresponding Email: arjanlombok@gmail.com
}

\begin{abstract}
The purpose of this study is to analyze the Implementation of DPS Supervision on Sharia Products PT. Bank NTB Syariah Post-conversion and analyze the Legal Consequences of Supervision by DPS Against PT Products. Bank NTB Syariah, If Not In Accordance with Sharia Principles. Normative-empirical research methods. Research approaches are Legal Approach, Historical Approach and Legal Sociology Approach. Types and data sources are secondary data and primary data. Research location at PT. Bank NTB Syariah. Data collection techniques or legal materials are techniques for the collection of secondary materials and primary materials. Data processing is processed in a coherence and systematic. The data analysis in this study is qualitative, comprehensive, and complete. The results of the study, First, based on the results of supervision for two years post-conversion, DPS said that, in general, company operational activities. Bank NTB Syariah is in accordance with Sharia Principles, Fatwa DSN-MUI and DPS Sharia Opinion from the results of supervision of SHARIA products of PT. Bank NTB Syariah. Second, If the product developed and marketed is correct from the concept side, in practice there is a mistake / error that results in the product does not meet the pillars and conditions of the contract, then the profit obtained from the contract transaction is not valid as the Bank's income, but becomes TBDSP funds. Against existing products, there is a discrepancy with sharia principles and DSN-MUI fatwas, the consequences of which can be frozen or discontinued. Settlement continues the payment transaction until it is paid off or the customer must pay off immediately
\end{abstract}

Keywords: Supervision, DPS, Sharia Banking Products.

DOI: $10.7176 / \mathrm{JLPG} / 108-11$

Publication date: April $30^{\text {th }} 2021$

\section{Introduction}

The transformation into a Sharia Commercial Bank is a strategic decision that brings about a fundamental change in PT's activities. Bank NTB Syariah. Various achievements and awards obtained since being converted into Sharia Commercial Banks (BUS) show significant developments in the banking world. Implementation of the regulation contained in Law No. 21 of 2008 concerning Sharia Banking to the Sharia Supervisory Board (DPS) in the duties and functions of the implementation of supervision of Sharia Business products in PT. Bank NTB Syariah, whether it has been run in accordance with existing norms or even vice versa.

The problem in this study is about the Implementation of Sharia Supervisory Board Supervision on PT Products. Bank NTB Syariah Post-conversion and Legal Consequences supervision by sharia supervisory board on PT. Bank NTB Syariah If Not In Accordance With Sharia Principles.

The purpose of this study is to Analyze the Implementation of Sharia Supervisory Board Supervision on Sharia Products PT. Bank NTB Syariah Post-conversion and Analyzing the Consequences of Supervision Law by sharia supervisory board on PT Products. Bank NTB Syariah If Not In Accordance With Sharia Principles.

The benefits of research, namely First, scientifically, to support the reference of legal science in general and especially in the knowledge of the Islamic banking system. Second, practical benefits, namely contributing to the practice of law in the field of Sharia Banking.

\section{Research methods}

The research method is normative-empirical.(Muhaimin, 2020) Research approaches are Legal Approach, Historical Approach,(Asikin, 2016) and Legal Sociology Approach.(Salim \& Nurbani, 2013) Types and data sources are secondary data and primary data. Research location at PT. Bank NTB Syariah. Data collection techniques or legal materials include secondary material collection techniques and primary data collection. Data processing is processed in a runut and systematic. The data analysis in this study is qualitative, comprehensive, and complete.(Muhaimin, 2020) 


\section{Results and discussion}

3.1 Sharia Supervisory Board (DPS) Supervision Implementation of PT. Post-Convertible Sharia NTB Bank

The legal basis for the Sharia Supervisory Board (DPS) on the duties and functions of supervision of Sharia Banking Products is contained in several laws and other regulations, including Law Number 40 of 2007 concerning Limited Liability Companies, these provisions are described in Article 109, Paragraph ( 1) Companies that carry out business activities based on sharia principles in addition to having a Board of Commissioners are required to have a Sharia Supervisory Board, (2) The Sharia Supervisory Board as referred to in paragraph (1) consists of one or more sharia experts who are appointed by the GMS on the recommendation of the Indonesian Ulama Council, and (3) The Sharia Supervisory Board as referred to in paragraph (1) is tasked with providing advice and suggestions to the Board of Directors as well as supervising the Company's activities to comply with sharia principles. In Law No. 21 of 2008 concerning Sharia Banking, as stipulated in the provisions of Article 32, Paragraph (1) The Sharia Supervisory Board must be established in Sharia Banks and Conventional Commercial Banks that have UUS, (2) The Sharia Supervisory Board as referred to in paragraph (1) shall be appointed by the General Meeting. Shareholders upon the recommendation of the Indonesian Ulema Council, (3) The Sharia Supervisory Board as referred to in paragraph (1) shall be tasked with providing advice and suggestions to the board of directors as well as supervising Bank activities in accordance with Sharia Principles; and (4) The Sharia Supervisory Board as referred to in paragraph (1) is regulated by a Bank Indonesia Regulation. Bank Indonesia Regulation Number: 11/3 / PBI / 2009 Concerning Islamic Commercial Banks, Bank Indonesia Regulation Number: 11/33 / PBI / 2009 Concerning Implementation of Good Corporate Governance for Sharia Commercial Banks and Sharia Business Units, Financial Services Authority Regulation Number 30 / POJK.05 / 2014 concerning Good Corporate Governance for Financing Companies, and Bank Indonesia Circular Letter No. 12/13 / DPbS, 30 April 2010, Regarding: Implementation of Good Corporate Governance for Sharia Commercial Banks and Sharia Business Units.

The implementation of supervision by the Sharia Supervisory Board of PT. Bank NTB Syariah regarding the process of developing new bank products, as follows:

1. Request an explanation from the authorized Bank official regarding the objectives, characteristics, and contract used in the new product to be issued;

2. Check whether the contract used in the new product has a fatwa from the National Sharia Council-Indonesian Ulama Council.

a. In the event that there is a fatwa, the Sharia Supervisory Board will analyze the suitability of the new product contract with the fatwa of the National Sharia Council-Indonesian Ulama Council;

b. In the event that there is no fatwa, the Sharia Supervisory Board proposes to the Board of Directors of the Bank to complete the new product agreement with a fatwa from the National Sharia Council-Indonesian Ulama Council.

3. Reviewing systems and procedures for new products to be issued related to compliance with Sharia Principles; and

4. Providing Islamic opinion on new products to be issued.

It is also explained in POJK Number 24 / POJK-03/2015 concerning Products and Activities of Sharia Banks and Sharia Business Units, provisions for compliance with sharia principles and customer protection principles, as described in Article 18, Paragraph (1) Banks are required to apply Sharia Principles in issuing products and / or carrying out Activities, (2) Fulfillment of the application of Sharia Principles as referred to in paragraph (1), must be supported by:

1. Fatwa of the National Sharia Council of the Indonesian Ulama Council which is the basis for the issuance of Products and / or implementation of Activities; and

2. Opinion from the Bank's Sharia Supervisory Board on Products and / or Activities.

In carrying out its supervisory duties, the Sharia Supervisory Board collaborates with the Compliance Work Unit and Internal Audit to ensure the Bank's compliance in implementing sharia principles. In essence, the Sharia 
Supervisory Board carries out duties and responsibilities based on the principles of Good Corporate Governance (GCG), as well as conducting consultations, providing advice and advice to the Board of Directors, Divisions related to the implementation of Bank activities to comply with sharia principles.

In Bank Indonesia Regulation Number: 11/33 / PBI / 2009 concerning Implementation of Good Corporate Governance for Sharia Commercial Banks and Sharia Business Units, in particular Article 46, DPS stipulates Duties, Authorities and Responsibilities. Implementation of the Supervisory Function of the Sharia Supervisory Board referred to in the Annual report of PT. Bank NTB Syariah which is implemented by the Sharia Supervisory Board on the following Duties and Responsibilities: ${ }^{1}$ :

1. Assess and ensure compliance with sharia aspects of operational guidelines and products issued by the bank;

2. Requesting a fatwa from the National Sharia Council of the Indonesian Ulema Council (DSN-MUI) on new bank products for which there is no fatwa;

3. Conduct periodic reviews of compliance with sharia principles on the mechanism for raising funds and channeling funds as well as bank services;

4. Requesting data and information related to sharia aspects from bank work units in the context of implementing DPS duties;

5. Open a consultation room for unclear / unclear problems with management and work units at any time needed.

In the implementation of Supervision, the Sharia Supervisory Board is carried out through the following work mechanisms:

1. Analyze reports submitted by and / or requested from work units to determine the quality of implementation of Sharia Principles compliance with activities of channeling and collecting funds as well as Bank services;

2. Determine the number of sampling (sample) transactions to be examined, each 10 (ten) files for each type of financing every month at the Branch Office and each 5 (five) files for each Sub-Branch Office every month by taking into account the quality of implementation. fulfillment of Sharia Principles in each transaction activity;

3. Approaching the First Semester and Second Semester of each year, the Sharia Supervisory Board of Bank NTB Syariah conducts an internal meeting to determine all branch offices to be picked for inspection;

4. Checking transaction documents that are tested by quotation to determine compliance with Sharia Principles as required in the applicable internal Bank regulations. The focus of the examination of DPS Bank NTB Syariah is on the fulfillment of aspects of sharia / sharia compliance, including:

a. The suitability of the contract used;

b. The fulfillment of the said contract elements in a financing scheme;

c. Examination of Financing Application Approval Letter (SP4 and SKP), Financing Analysis Note (NAP), Akad and Notarial Deed.

5. Conducting inspections, observations, requests for information, and / or confirmation to Bank employees and / or customers to strengthen the results of document inspection;

6. Reviewing applicable internal provisions related to sharia aspects if there are indications of non-compliance with the implementation of Sharia Principles;

7. Provide sharia opinion on fundraising and fund distribution activities, as well as Bank services;

8. The special SSB Sharia Opinion for this is a requirement that must be fulfilled by NTB Syariah banks in order to fulfill the requirements of the annual financial report audit process for Bank NTB Syariah.

${ }^{1}$ Ibid. Hal. 260. 
Implementation of duties and responsibilities of the Sharia Supervisory Board in the annual report of PT. Sharia NTB Bank in 2019 as follows:

1. Provide an opinion from the aspect of sharia on the implementation of bank operations as a whole in the bank publication report;

2. Submit a report on the results of supervision every 6 (six) months to the Board of Directors, Commissioners, National Sharia Board and the Financial Services Authority.

The mechanism for implementing the DPS supervision report to the Board of Directors, the Board of Commissioners, and the Financial Services Authority includes documentation of DPS activities compiled on a semi-annual basis, including:

1. The results of supervision of the Bank's product development process include objectives, characteristics, contract in the product, compliance with sharia principles and the DSN-MUI Fatwa, review of systems and procedures for product distribution;

2. The results of supervision of the Bank's activities include raising funds, channeling funds, and providing services. The forms of supervision are in the form of:

a. Determination and examination of the number of transaction sampling tests;

b. Review of Standard Operational Procedure (SOP) related to aspects of Sharia.

3. Opinion of the Sharia Supervisory Board (DPS) on Bank operations per period, namely:

a. The first semester from January to June 2019 and;

b. Second semester from July to December 2019.

There were 11 (eleven) DPS Opinions from January to June 2019, while the DPS Opinions from July to December 2019 were 13 opinions.

Based on the results of supervision during 2019, the Sharia Supervisory Board said that in general the operational activities of PT. Bank NTB Syariah is in accordance with Sharia Principles, Fatwa DSN-MUI and DPS Opinion. Errors or deficiencies that occur in operational activities do not lead to errors in making policies, but rather to individual understanding of a product and the Bank's Operational Guidelines.

\subsection{Legal Consequences of Sharia Supervisory Board Supervision of PT. Sharia NTB Bank If Not In Accordance With Sharia Principles}

PT. Bank NTB Syariah is committed to continuing to innovate and adapt to changes and developments in the fast and increasingly competitive Sharia Banking industry in order to meet customer needs for banking transactions that comply with Sharia principles. The business activities of PT. Bank NTB Syariah is categorized into several products that are focused on in this study, namely savings products and financing products with the following explanation:

\section{Savings Products}

In the savings product of PT. Bank NTB Syariah uses several contracts according to sharia principles, including:

a. The Wadiah Yad Dhamanah contract, is a contract for safekeeping of goods or money where the recipient of the deposit with or without the permission of the owner of the goods can use the goods or money deposited and must be responsible for the loss or damage of the goods.

b. The Mudharabah Muthlaqah (Al-Hasni, 2017)agreement is a form of cooperation that gives mudharib freedom to manage capital in any form of business that can bring profit as long as it does not conflict with the principles of shari'ah.

\section{Financing Products}

In the financing product of PT. Bank NTB Syariah, there are 4 (four) types of sharia contracts as follows:

a. Murabahah agreement is a muamalah transaction contract by applying the principle of buying and selling 
goods at the cost of the goods plus the margin agreed upon by the parties.(Hakim \& Anwar, 2017) Murabaha is buying and selling at an initial price plus a profit.(Mukhlas, 2019) According to the DSN-MUI Fatwa Number 04 of 2000, murabaha is selling an item by confirming the purchase price to the buyer and the buyer pays a higher price as profit.

b. Ijarah agreement, according to Fatwa DSN-MUI Number 09 of 2000, Ijarah is an agreement to transfer the use rights (benefits) of an item within a certain time with rental payments (ujrah), without being followed by transfer of ownership of the goods themselves. Ijarah in the context of Islamic banking is a lease contract. A lease contract is a financial institution renting out equipment (equipment), either in the form of a building or goods, such as machines, airplanes, etc. to one of its customers based on a predetermined fee. "(Mukhlas, 2019)

c. Musharaka contract is a cooperation agreement between two or more parties for a particular business. Where each party contributes funds (or charity / expertise) with the agreement that the benefits and risks will be shared according to the agreement. This type of contract is also known as profit \& loss sharing.(Mukhlas, 2019)

d. The Musyarakah Mutanaqisah Akad is a sharia banking financing product based on the principles of syirkah 'inan, where the portion (hishshah) of one of the shari's (Bank) capital is reduced due to a gradual commercial purchase or transfer (naqlul hishshah bil' iwadh mutanaqishah) to another sharik (customer).(Mukhlas, 2019) "Musyarakah mutanaqishah is a derivative product of the musyarakah contract, which is a form of cooperation agreement between two or more parties. Syarif Puad stated that Musyarakah Mutanaqisah, in the practitioner's view, will carry out an assessment through contract review, in the Mutanaqisah Community agreement, there are 3 (three) main forms of agreement, namely a joint venture agreement, a lease agreement / ijarah, and a sale and purchase agreement.

\subsection{Legal Consequences If Bank NTB Syariah Products Are Not In Accordance With Sharia Principles}

Law Number 21 of 2008 concerning Sharia Banking, in the elucidation of Article 2, "Business activities based on Sharia Principles, among others, are business activities that do not contain the following elements:

1. Riba, which is an increase in income illegally (vanity), among others, in the exchange of similar goods that are not of the same quality, quantity, and delivery time (fadhl), or in lending and borrowing transactions which require the Facility Recipient Customer to return the funds received in excess of principal of the loan due to the passage of time (nasi'ah);

2. Maisir, namely transactions that depend on an uncertain and chancy nature;

3. Gharar, which is a transaction whose object is unclear, not owned, its whereabouts are unknown, or cannot be submitted at the time the transaction is carried out unless otherwise stipulated in sharia;

4. Haram, namely transactions whose objects are prohibited in sharia; or

5. Zalim, namely transactions that cause injustice to other parties..

\subsection{Product Consequences If Not In Accordance With Sharia Principles}

Whenever the products developed and marketed by PT. Bank NTB Syariah is correct in terms of concept, but then in practice there are errors or errors that result in the product not fulfilling the terms and conditions of the contract, so the profits obtained from the contract transaction are not valid as sharia banking income, but become unauthorized funds. Recognized as Income for Sharia Financial Institutions, Sharia Business Institutions, and Sharia Economic Institutions (TBDSP).(Sholihin, 2021) Described in the DSN-MUI Fatwa Number: 123 / DSNMUI / XI / 2018 concerning the Use of Funds That Cannot Be Recognized as Income for Sharia Financial Institutions, Sharia Business Institutions, and Sharia Economic Institutions. In the general provisions, number 1, "Funds that cannot be recognized as income for Islamic financial institutions, sharia business institutions and sharia economic institutions, hereinafter referred to as TBDSP funds, are funds received or controlled by LKS, LBS and LPS, but may not recognized as income or wealth. " The provisions related to TBDSP funds are explained as follows:

a. TBDSP funds come from, among others:

1. Unavoidable transactions not in accordance with sharia principles, including interest income (usury);

2. Sharia transactions that are not fulfilled the terms and conditions (pillars and / or conditions);

3. Funds for sanctions (fines) for not fulfilling the obligations according to the agreement ('adam al-wafa' bi al-iltizam); 
4. Funds that are not known to the owner, known to the owner but not found, or known to the owner, but the cost of returning them is greater than the amount of the funds.

b. Funds in letter a, number 4, may be recognized as TBDSP Funds after one year since they are announced unless otherwise stipulated by the prevailing laws and regulations;

c. LKS, LBS and LPS are required to form a special account for the storage of TBDSP Funds.

With regard to products that are already running, under the supervision of the Sharia Supervisory Board it is found that they are incompatible with sharia principles and the DSN-MUI fatwa, so the consequences of these products can be frozen or temporarily suspended and permanently suspended / revoked. If this is the case, then marketing of the product will be terminated, as for products that are already running, there is a settlement by continuing the payment transaction until it is paid off or the customer must pay it off immediately.(Sholihin, 2021) In the provisions of CHAPTER IV, Bank Indonesia Regulation Number: 10/17 / PBI / 2008 concerning Products of Sharia Banks and Sharia Business Units, it is explained in Article 7 as follows: "Banks are required to stop Product activities in the event that:

1. The Bank does not comply with the provisions referred to in Article 2, or Article 3 paragraph (3);

2. The product is not in accordance with the Sharia Principles; or

3. The product is not in accordance with the applicable laws and regulations. "

In the provisions of Article 8, it is further explained as follows:

1. Bank Indonesia may request a Bank to stop Product activities as referred to in Article 7;

2. Termination of Product activities as intended in paragraph (1) can be permanent or temporary;

3. In the event that the Product is subject to a temporary suspension:

a. Banks are required to improve the Product in question within the time frame determined by Bank Indonesia;

b. Banks are temporarily prohibited from selling the Products;

c. Temporary suspension can be revoked if the Bank has perfected the Product;

d. In the event that the Bank is unable to complete the Product in question within the timeframe determined by Bank Indonesia, the Product may be subject to permanent termination.

4. In the event that a Product is subject to permanent termination, the Bank is obliged to stop Product activities and settle the rights and obligations of the intended Product customer within a period determined by Bank Indonesia.

\section{Conclusion}

In general, the operational activities of PT. Bank NTB Syariah is in accordance with the Sharia Principles, Fatwa DSN-MUI and DPS Opinion from the results of supervision of the sharia products of PT. Sharia NTB Bank. Errors or deficiencies that occur in operational activities do not lead to errors in making policies, but rather to individual understanding of a product and the Bank's Operational Guidelines.

From the results of DPS supervision, if in practice there is an error or error that results in the product not meeting the terms and conditions of the contract, then the profits obtained from the contract transaction are not valid as bank income, but become funds that cannot be recognized as income for Islamic financial institutions. , Sharia Business Institutions, and Sharia Economic Institutions (TBDSP). For a product that is already running, if it is found that it is inconsistent with sharia principles and the DSN-MUI fatwa, then the consequences of the product can be temporarily suspended or frozen or permanently suspended. Marketing of the related product has been stopped. For products that are already running, there is a settlement by continuing the payment transaction until it is paid off or the customer must pay it off immediately.

\section{References}

\section{Book}

Al-Hasni, F. (2017). Akad Mudharabah Mutlaqah dalam Praktik Perbankan Syariah. Mu'amalat: Jurnal Kajian Hukum Ekonomi Syariah, 9(2), 208-222.

Asikin, Z. (2016). Pengantar metode penelitian hukum.

Hakim, L., \& Anwar, A. (2017). Pembiayaan Murabahah Pada Perbankan Syariah Dalam Perspektif Hukum Di 
Indonesia. Al-Urban: Jurnal Ekonomi Syariah Dan Filantropi Islam, 1(2), 212-223.

Muhaimin. (2020). Metode Penelitian Hukum. Mataram University Press, Mataram, 2020.

Mukhlas, O. S. (2019). Dual Banking System \& Penyelesaian Sengketa Ekonomi Syariah. Bandung: PT Refika Aditama.

Salim, H. S., \& Nurbani, E. S. (2013). Penerapan Teori hukum pada penelitian tesis dan disertasi. Raja Grafindo Persada, Jakarta.

Sholihin, A. I. (2021). Praktisi dan konsultan perbankan syariah.

\section{Documents}

PT. Bank NTB Syariah, Melangkah Maju Membangun Bisnis Berkualitas, Laporan Tahunan 2019.

Laporan Tahunan Bank NTB Syariah Tahun 2018.

\section{Interview Results}

Syarif Fuad, Staf Ahli Dewan Pengawas Syariah PT. Bank NTB Syariah, Wawancara pada tanggal 26 Februari 2021.

Ahmad Ifham Sholihin, Praktisi dan konsultan perbankan syariah, 2 Maret 2021.

\section{Internet}

Abdul Rasyid, Jaminan Fidusia Pada Akad Murabahah, https://business-law.binus.ac.id, Juni 2017.

Dendy Herdianto, Akad Wadiah dalam Ekonomi Islam, https://qazwa.id. 13 Mei 2019.

Rizki Adi Santoso, Wadi’ah Yad Dhamanah, https://www.kompasiana.com, 6 Mei 2016.

https://www.bankntbsyariah.co.id.

\section{Fatwa DSN-MUI}

Fatwa DSN-MUI Nomor : 123/DSN-MUI/XI/2018 Tentang Penggunaan Dana Yang Tidak Boleh Diakui Sebagai Pendapatan Bagi Lembaga Keuangan Syariah, Lembaga Bisnis Syariah, dan Lembaga Perekonomian Syariah. 